Argonne

ANL-20/51

\title{
Used Plug-in Electric Vehicles as a Means of Transportation Equity in Low-Income Households
}

A Literature Review

Energy Systems Division 


\section{About Argonne National Laboratory}

Argonne is a U.S. Department of Energy laboratory managed by UChicago Argonne, LLC under contract DE-AC02-06CH11357. The Laboratory's main facility is outside Chicago, at 9700 South Cass Avenue, Argonne, Illinois 60439. For information about Argonne and its pioneering science and technology programs, see www.anl.gov.

\section{DOCUMENT AVAILABILITY}

Online Access: U.S. Department of Energy (DOE) reports produced after 1991 and a growing number of pre-1991 documents are available free at OSTI.GOV (http://www.osti.gov/), a service of the US Dept. of Energy's Office of Scientific and Technical Information.

Reports not in digital format may be purchased by the public from the National Technical Information Service (NTIS):

U.S. Department of Commerce

National Technical Information Service

5301 Shawnee Rd

Alexandria, VA 22312

www.ntis.gov

Phone: (800) 553-NTIS (6847) or (703) 605-6000

Fax: (703) 605-6900

Email: orders@ntis.gov

Reports not in digital format are available to DOE and DOE contractors from the Office of Scientific and Technical Information (OSTI):

U.S. Department of Energy

Office of Scientific and Technical Information

P.O. Box 62

Oak Ridge, TN 37831-0062

www.osti.gov

Phone: (865) 576-8401

Fax: (865) 576-5728

Email: reports@osti.gov

\section{Disclaimer}

This report was prepared as an account of work sponsored by an agency of the United States Government. Neither the United States Government nor any agency thereof, nor UChicago Argonne, LLC, nor any of their employees or officers, makes any warranty, express or implied, or assumes any legal liability or responsibility for the accuracy, completeness, or usefulness of any information, apparatus, product, or process disclosed, or represents that its use would not infringe privately owned rights. Reference herein to any specific commercial product, process, or service by trade name, trademark, manufacturer, or otherwise, does not necessarily constitute or imply its endorsement, recommendation, or favoring by the United States Government or any agency thereof. The views and opinions of document authors expressed herein do not necessarily state or reflect those of the United States Government or any agency thereof, Argonne National Laboratory, or UChicago Argonne, LLC. 


\section{Used Plug-in Electric Vehicles as a Means of Transportation Equity in Low-Income Households}

A Literature Review

prepared by

Olumide Winjobi and Jarod C. Kelly

Energy Systems Division, Argonne National Laboratory

April 2021 



\section{Errata: \\ Used Plug-in Electric Vehicles as a Means of Transportation Equity in Low-Income Households: A Literature Review}

- Changed the publication date to April 2021.

- Added hyperlinks to the table of contents.

- Corrected typographical errors.

- Updated content about the availability of CVAP funding in Section 4.2, Monetary Incentives: "As of December 2019, the CVAP is not accepting applications for the grant" is now "As of March 2021, due to limited funding, CVAP is providing grants to applicants on a first-come, first-serve basis").

- Added color to Figure 4 and Figure 11 for clarity.

- Updated reference 3 to refer to the $38^{\text {th }}$, rather than the $35^{\text {th }}$, edition of the Transportation Energy Data Book. 


\section{CONTENTS}





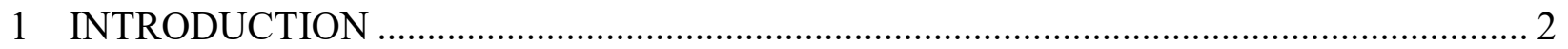

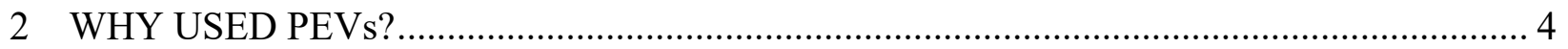

3 BARRIERS TO PEV ADOPTION IN LOW-INCOME COMMUNITIES ……....................... 6



3.2 Low Availability of Public Charging Stations ………................................................. 7



4 PROGRAMS TO ASSIST IN USED PEV ADOPTION ……................................................ 10

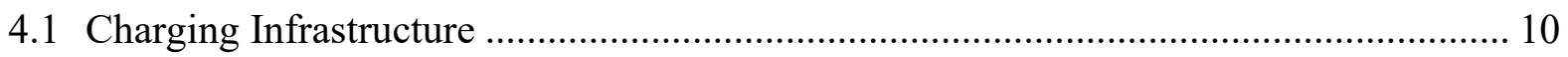

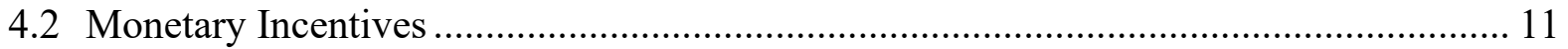



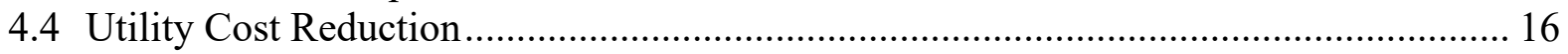

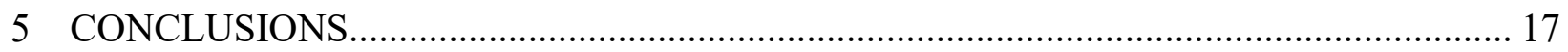



\section{FIGURES}

1 People in households without a vehicle based on income level in the

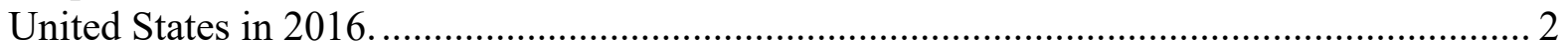

2 U.S. households with PEVs based on household income in 2017 ........................................ 4

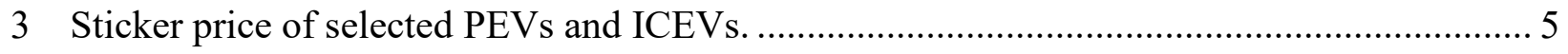

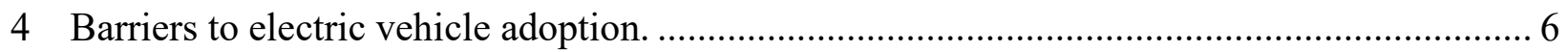

5 Percentage of electric vehicle households that use home and public charging in different



6 Pre- and post-drive opinions for PEVs in Midwest United States........................................ 9

7 The number of public charging stations in the United States from 1989 to 2019.................. 10

8 State and utility monetary incentives through grants or rebates for used PEVs

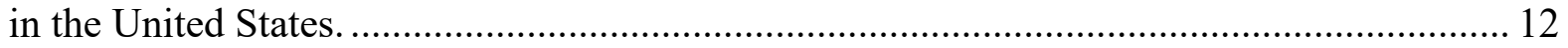

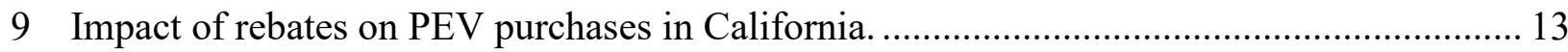

10 Incentives for PEVs in the form of rebates for electric-vehicle-charging infrastructure or electric vehicle registration.

11 Comparison of the main barriers to PEV adoption between total driver population and existing PEV owners. 


\section{TABLE}

1 The number of public charging outlets in select states in the United States........................ 11 


\section{ACKNOWLEDGMENTS}

This work was supported by the Vehicles Technologies Office, Office of Energy Efficiency and Renewable Energy, United States Department of Energy under Contract Number DE-AC02-06CH11357. The authors would like to thank Linda Bluestein, Marcy Rood, and Yan Zhou for their guidance and feedback.

This report was prepared as an account of work sponsored by an agency of the United States government. Neither the United States government nor any agency thereof, nor any of their employees, makes any warranty, express or implied, or assumes any legal liability or responsibility for the accuracy, completeness, or usefulness of any information, apparatus, product, or process disclosed or represents that its use would not infringe privately owned rights. Reference herein to any specific commercial product, process, or service by trade name, trademark, manufacturer, or otherwise does not necessarily constitute or imply its endorsement, recommendation, or favoring by the United States government or any agency thereof. The views and opinions of the authors expressed herein do not necessarily state or reflect those of the United States government or any agency thereof. 
This page left intentionally blank. 


\begin{abstract}
This report examines improving the equity of low-income households through access to reliable means of transportation. Used plug-in electric vehicles (PEVs) can serve as a low-cost and low-maintenance means of transport for lowincome households. Zero tail-pipe emissions from PEVs is also a benefit of these drivetrains compared to internal combustion engine vehicles (ICEVs). Barriers to the adoption of the used PEVs, and incentives that may address these barriers, are reviewed.
\end{abstract}




\section{INTRODUCTION}

Vehicle ownership generally increases access to essential local services and amenities, such as employment, grocery shopping, medical services, and so forth. However, a significant number of low-income households do not own any vehicles, thereby limiting the access of such households to these essential services. ${ }^{[1]}$ A 2012 survey of 698 low-income patients' transportation to public outpatient clinics in a suburb of New York City reported that "patients who took public transit to the doctor's office were twice as likely to miss appointments as patients who drove vehicles." ${ }^{\text {[2] }}$ Second only to housing, transportation is a significant household expenditure, accounting for about $15.9 \%$ of the average annual spending of all households in the United States, and the cost of vehicle purchase is the highest single contributor to transportation expenditures. ${ }^{[3]}$ Vehicle operating costs, such as maintenance, are also not negligible. Increasing the number of low-income households with access to vehicles would require an approach that provides both low purchase cost and low maintenance cost vehicles. Figure 1 shows that in 2016, households with annual incomes below the poverty level in the United States had a higher rate of not having a vehicle than households above the poverty level. ${ }^{[4]}$ For households with incomes lower than $50 \%$ of the poverty level, $18 \%$ were zero-vehicle households compared to about $3 \%$ for households whose income was more than $200 \%$ of the poverty level. ${ }^{[4]}$



FIGURE 1 People in households without a vehicle based on income level in the United States in 2016. (Reproduced from Jones et al. ${ }^{[4]}$ )

A study by Pendall et al. showed that households with cars "tend to live and remain in higher opportunity neighborhoods - places with lower poverty rates, higher social status, stronger housing markets, and lower health risks. ${ }^{"[5]}$ Pendall et al. also stated that "the importance of low-income households having access to cars becomes evident in metropolitan 
areas where the public transit systems are usually slow and also sometimes lack metropolitanwide coverage." ${ }^{[5]}$ Access to vehicles in the suburbs is also of paramount importance. A 2011 study by the Metropolitan Policy Program at the Brookings Institution stated that "a 25.4\% transit share for households without vehicles in the suburbs relative to $59.7 \%$ of households in the metropolitan areas utilized the public transit system for commuting which implied that threequarters of households in the suburbs needed an alternative mode of transport to get to work."[6] Without a reliable form of transportation, households without vehicles, which are mostly lowincome households, generally have a shorter radius of travel than high-income households, thereby limiting their access to jobs and services.

Through multivariate analysis, Garasky et al. showed that employment and reliable transportation are related. ${ }^{[7]}$ In their 2006 study, Garasky et al. reported that among those they surveyed, households without access to a reliable vehicle were less likely to be employed. ${ }^{[7]}$ Another study that looked at the success of Welfare to Work programs near Minneapolis, Minnesota, found that $70 \%$ of the jobs that were available to low-income workers were scattered throughout surrounding suburban areas that were not well served by public transit. ${ }^{[8,9]}$ The Welfare to Work study highlighted limited mobility as one of the barriers to available jobs for low-income households. For most low-income households to transition to higher-wage jobs, they need access to reliable transportation, so increasing the access to reliable vehicles could play a critical role.

In addition to economic security challenges, some of these low-income communities are located along congested highways, thereby falling into the category of areas with high pollution such as the San Joaquin Valley in California. Padula et al. in their study associated the increased risk of preterm birth with exposure to traffic-related air pollution. ${ }^{[10]}$ Clark et al. reported a high concentration of nitrous oxides $\left(\mathrm{NO}_{\mathrm{x}}\right)$, typically emitted from combustion in vehicles and power plants, in low-income communities relative to high-income communities. ${ }^{[1]}$ While there is a push toward cleaner communities through car-sharing, vehicle access is still essential for families in low-income communities seeking to improve their economic security. One way of improving the access of these households to vehicles while ensuring a cleaner environment would be through increasing the participation of these communities in the electric vehicle market through inexpensive or subsidized pre-owned plug-in electric vehicles (PEVs). 


\section{WHY USED PEVs?}

PEVs, a term encompassing plug-in hybrid vehicles (PHEVs) and battery electric vehicles (BEVs), offer advantages over conventional internal combustion engine vehicles (ICEVs). These advantages include increased powertrain efficiency, decreased maintenance requirements, and zero tailpipe emissions (for BEVs, and PHEVs when they use only battery power), with the last benefit contributing to air pollution reduction relative to ICEVs. ${ }^{[12,13]}$ Although there has been a significant increase in the number of PEVs purchased in the United States, rising from about 50,000 in 2012 to about 360,000 in 2018, the share of PEV owners is dominated by high-income households, as shown in Figure 2. ${ }^{[14]}$ Households with incomes higher than $\$ 75,000$ account for about $79 \%$ of households with PEV ownership, while households with incomes less than $\$ 50,000$ account for only about $8 \%$ of PEV-owning households.

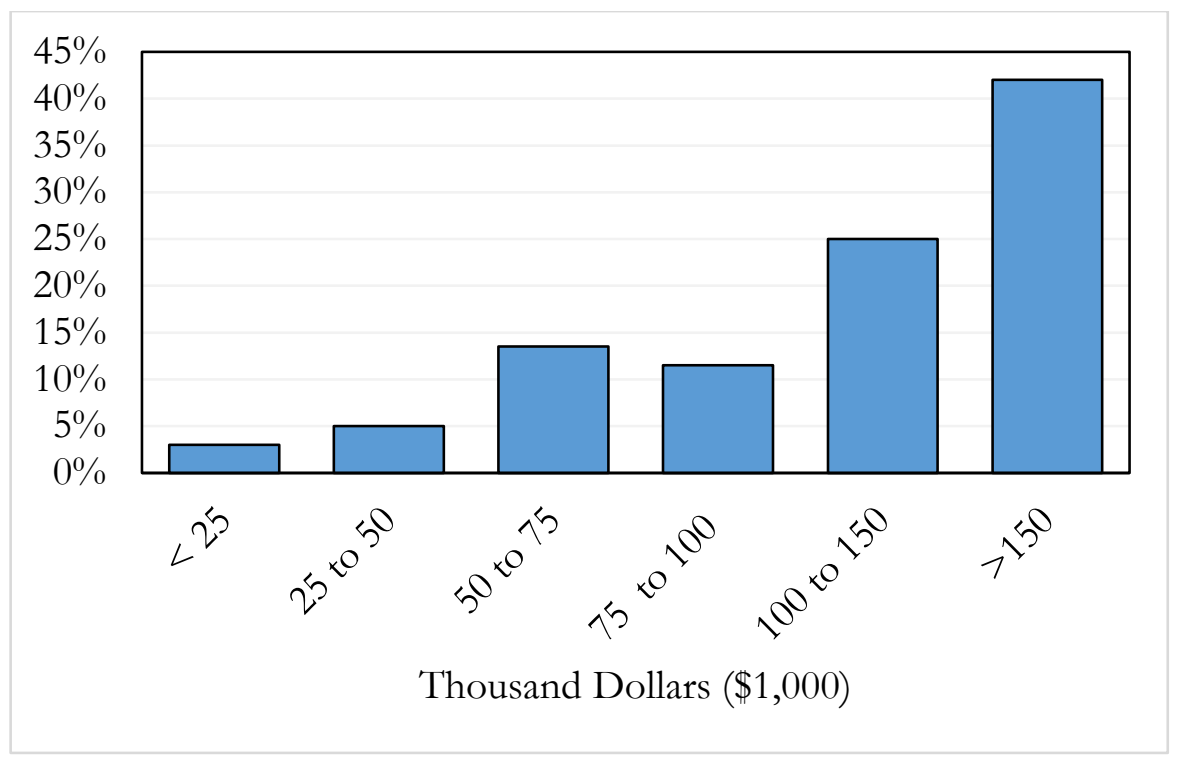

FIGURE 2 U.S. households with PEVs based on household income in 2017. (Source: U.S. Energy Information Administration ${ }^{[15]}$ )

The initial purchase (sticker) prices of PEVs, after federal incentives, are generally higher than those of comparable conventional vehicles, as shown in Figure 3. The cost of the vehicle battery is a significant contributor to the price of PEVs; a McKinsey report stated a difference of about $\$ 12,000$ in the production cost of PEVs compared to that of ICEVs. ${ }^{[16]}$ Used PEV purchase prices are, however, significantly lower (discussed later in Section 3.3) than those of used ICEVs, and PEVs are generally less costly to maintain and operate. PEVs have fewer moving parts, making them less expensive to maintain than ICEVs and less costly to operate in terms of fuel costs. For BEVs, the average fuel cost range is $\$ 421-\$ 485$ annually, compared to an average of $\$ 1,117-\$ 1,500$ for an ICEV, according to a study by Sivak and Schoettle that took variability in fuel costs across states in the United States into consideration and a Union of Concerned 
Scientists survey. ${ }^{[17]}$ Used PEVs may, therefore, serve as a low-cost and low-maintenance option for low-income households.



FIGURE 3 Sticker price of selected PEVs (price after federal tax credit in dark green bar and federal tax credit in light green bar) and ICEVs.

* ICEV prices obtained from Energysage.com ${ }^{[18]}$

* PEV prices (as of October 2019) from Midwest EV Info List ${ }^{[19]}$ 


\section{BARRIERS TO PEV ADOPTION IN LOW-INCOME COMMUNITIES}

Although used PEVs may offer a possible low-cost and low-maintenance option for improving the access of low-income households to services, amenities, and better economic conditions, there is low rate of PEV adoption among low-income households because of a number barriers, both singularly and in combination. Understanding these barriers may help illuminate solutions that can increase the adoption of PEVs in these households. These barriers include but are not limited to concern about the PEV running out of battery power, PEV purchase cost, and limited PEV models.

The results of a survey conducted by Volvo Car USA/The Harris Poll, as shown in Figure 4, show that the main barriers to purchasing PEVs (regardless of income level) were concerns about running out of power (58\%), low availability of charging points $(49 \%)$, and initial vehicle cost (48\%). ${ }^{[20]}$ Although the poll was not explicitly geared toward used PEVs, some of these concerns will likely translate to households considering buying used PEVs.

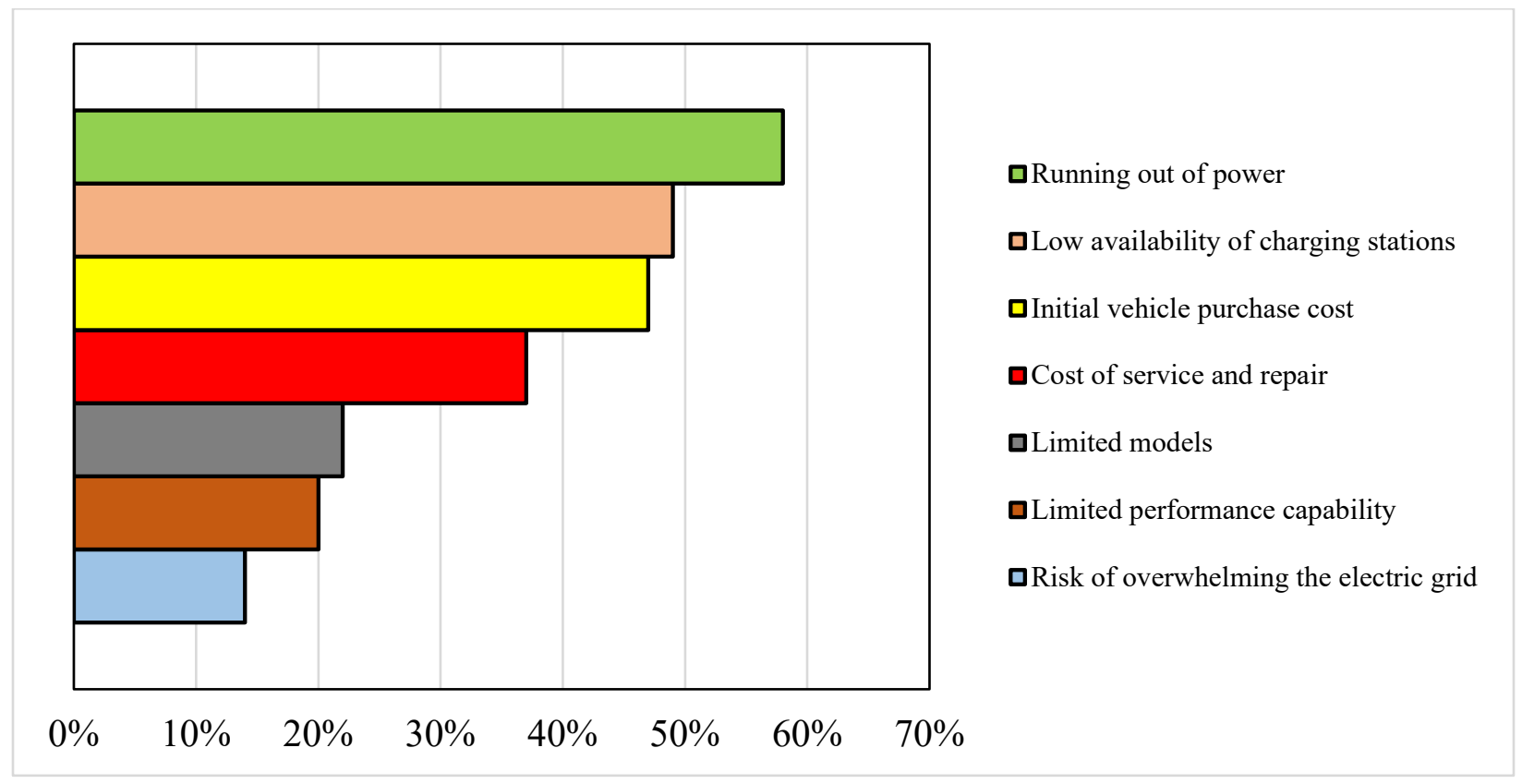

FIGURE 4 Barriers to electric vehicle adoption. (Recreated from EVAdoption ${ }^{[20]}$ )

\subsection{RUNNING OUT OF BATTERY POWER}

"Range anxiety" is the concern that a PEV will have insufficient battery charge to complete a journey. This concern is a result of a combination of factors, including the vehicle battery's capacity and access to charging infrastructure (discussed in Section 3.2), resulting in a perceived limited vehicle travel range. While the concern about running out of power was the leading barrier for $58 \%$ of the total drivers surveyed by Volvo/Harris, that percentage dropped to 
$38 \%$ when only current PEV drivers were polled, reflecting that the concern abates as PEV driving experience increases. ${ }^{[18]}$ Newer PEVs, such as the Tesla Models S, X, and 3 and Chevy Bolt, do have increased battery capacities, resulting in significantly longer ranges $(>200$ miles $)$ compared to the older-generation PEVs ( $<100$ miles) on a single charge; this should reduce range anxiety. The increased capacity of these newer PEVs, however, often comes with a higher price. This range versus price trade-off may take these long-range PEVs out of the price range of lowincome households addressed in this report. With used PEVs, factors similar to those for new PEVs contribute to range anxiety. However, with used PEVs, their prior usage may result in reduced capacity of the battery pack relative to new PEVs. For instance, in addition to battery degradation from prior use, older PEVs such as the Nissan Leaf, with a relatively short range (official range of 100 miles), may result in a limited operating range of about 73 miles. ${ }^{[21]}$

\subsection{LOW AVAILABILITY OF PUBLIC CHARGING STATIONS}

Another barrier to adopting PEVs is the low availability of public charging stations (see Figure 4). As reported in USA Today, the U.S. Department of Energy projects that more than $90 \%$ of charging will take place in a residential setting; however, as Nicholas et al. reported, "access to home charging is closely correlated with home types." ${ }^{[22,23]}$ In their research, Nicholas et al. indicated that, in California, the highest percentage of electric vehicle buyers $(\sim 83 \%)$ were located in detached houses, compared to about $8 \%$ and $9 \%$ in attached houses and apartments, respectively. Davis reported that homeowners are three times more likely than renters to own an electric vehicle. ${ }^{[24]}$ When considering homeowners and renters within the same income level, between $\$ 75,000$ and $\$ 100,000$, Davis reported that 1 in 130 homeowners owned a PEV compared to 1 in 370 renters. ${ }^{[24]}$ One reason for the difference may be the relative ease of installing PEV-charging equipment in detached houses compared to attached houses and apartment buildings. A 2011 survey of more than 2000 new vehicle buyers reported that about half of the respondents did not have access to an electrical connection of 110-volt service or higher required for Levels 1 and 2 charging equipment within 25 feet of where they park. ${ }^{[25,26]}$ Aside from proximity to an electrical connection, typical landlord-tenant contracts in apartments (single- and multi-unit dwellings) may prevent renters from installing charging equipment. Multi-unit dwellings also typically have assigned parking spaces, making it more complicated to have PEV charging equipment installed for electric vehicle owners. ${ }^{[26]}$ Figure 5 shows the charging habits for electric-vehicle-owning households in California, by household type, for four different PEV types, ranging from 30-mile-range PHEVs to 150-mile-range BEVs, from the study by Nicholas et al. ${ }^{[22]}$ They excluded drivers of Tesla Model S and X from their survey because of Tesla's free supercharging and the high income of those households.

Figure 5 shows that residential Level 1 and 2 charging dominated the charging access for PEV owners in detached houses in California; about $90 \%$ of the respondents living in detached houses (based on a simple average of the four electric vehicle types surveyed) charged their PEVs at their homes; $49 \%$ of the respondents living in apartments used public charging; and about 33\% used residential charging, mainly Level 1. Low-income households generally tend to be renters, and increasing the access of such households to public charging infrastructure may be an incentive for such households to adopt low-cost and low-maintenance used PEVs. 


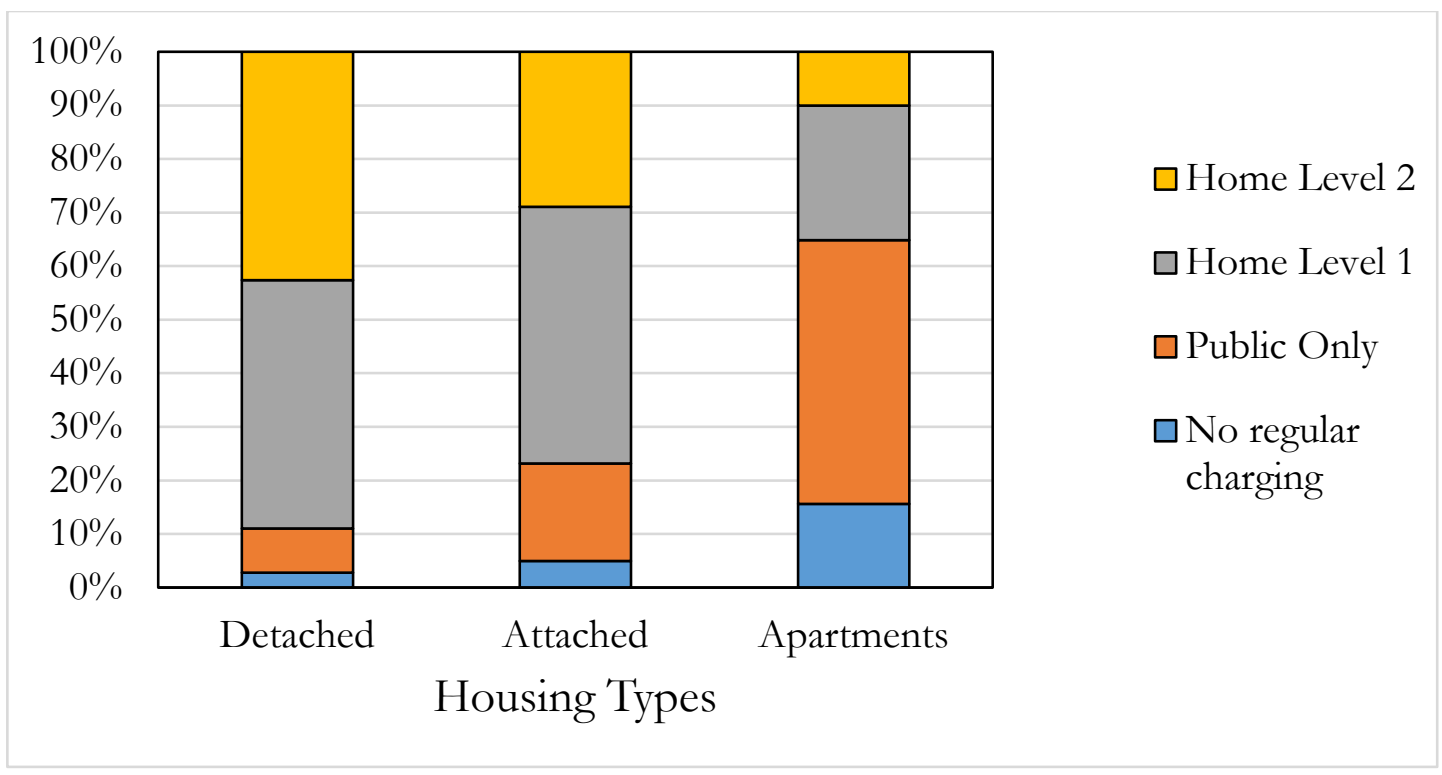

FIGURE 5 Percentage of electric vehicle households that use home and public charging in different housing types in California. ${ }^{[22]}$ (Estimated using a simple average of percentages stated by Nicholas et al. ${ }^{[22]}$ )

\subsection{INITIAL PURCHASE COST}

Initial purchase cost was also cited as a barrier to PEV ownership. As shown in Figure 3, PEVs are more expensive than comparable ICEVs, even after federal incentives, particularly those outside of the luxury market. However, PEVs have been reported to have higher depreciation rates than conventional vehicles, and this could potentially result in less expensive used PEVs. Some studies have reported lower resale values for used PEVs. ${ }^{[27-30]}$ Batchelor reported that the price of a 5-year-old PEV could decrease to $10 \%$ of its initial price based on ACF Finance prediction of a strong depreciation. ${ }^{[27]}$ Woodyard found low resale values for PHEVs after the first 3 to 5 years of ownership based on transaction prices of used PHEVs from model years 2011 through 2014. ${ }^{[28]}$ Guo and Zhou performed a residual value analysis of PEVs and compared them with other vehicle powertrain technologies. ${ }^{[29]}$ They found that after the first year, a mass-market BEV retains about $55 \%$ of its initial price compared to about $66 \%$ retained by a mass-market ICEV. Schoettle and Sivak reported that a BEV would retain about $21.2 \%$ of its initial manufacturer suggested retail price (MSRP) after six years compared to $27.9 \%$ and $32.3 \%$ retention for PHEVs and ICEVs, respectively. ${ }^{[30]}$ The significant difference in the MSRP retention may result in less expensive used PEVs compared to used ICEVs, thus making used PEVs a more affordable option for low-income households.

Although there has been a significant increase in the number of PEVs sold in the United States (from about 18,000 in 2011 to 360,000 in 2018), another barrier to PEV adoption is that there is still limited general knowledge of the benefits of PEVs and the incentives currently associated with PEV purchases. ${ }^{[14]}$ Krause et al. pointed out that there was a high degree of misinformation about the basic features of PEVs. ${ }^{[31]}$ In their study, more than $70 \%$ of survey respondents underestimated the extent of fuel savings for PEVs compared to that for gas- 
powered vehicles, while about $60 \%$ believed that the maintenance cost for PEVs was higher than that for ICEVs. A 2017 McKinsey survey of more than 3,500 potential buyers showed that although about $96 \%$ of the respondents in the United States and Germany were aware of PEVs, about 50\% were unsure of how PEVs operated. ${ }^{[32]}$ A 2019 survey by Zhou et al. gauged the opinions of survey respondents in the Midwest before and after driving a PEV. ${ }^{[33]}$ Zhou et al. observed that respondents were more likely to consider a PEV post-drive, as shown in Figure 6 . For PHEVs, the percentage of people likely to consider a PEV rose from $60 \%$ to $68 \%$ (72\% nationally), while for BEVs, the percentage rose from $56 \%$ to $63 \%$ (75\% nationally). ${ }^{[33]}$ National post-drive results indicated a $72 \%$ and $75 \%$ likelihood of considering the purchase of a PHEV and $\mathrm{BEV}$, respectively.

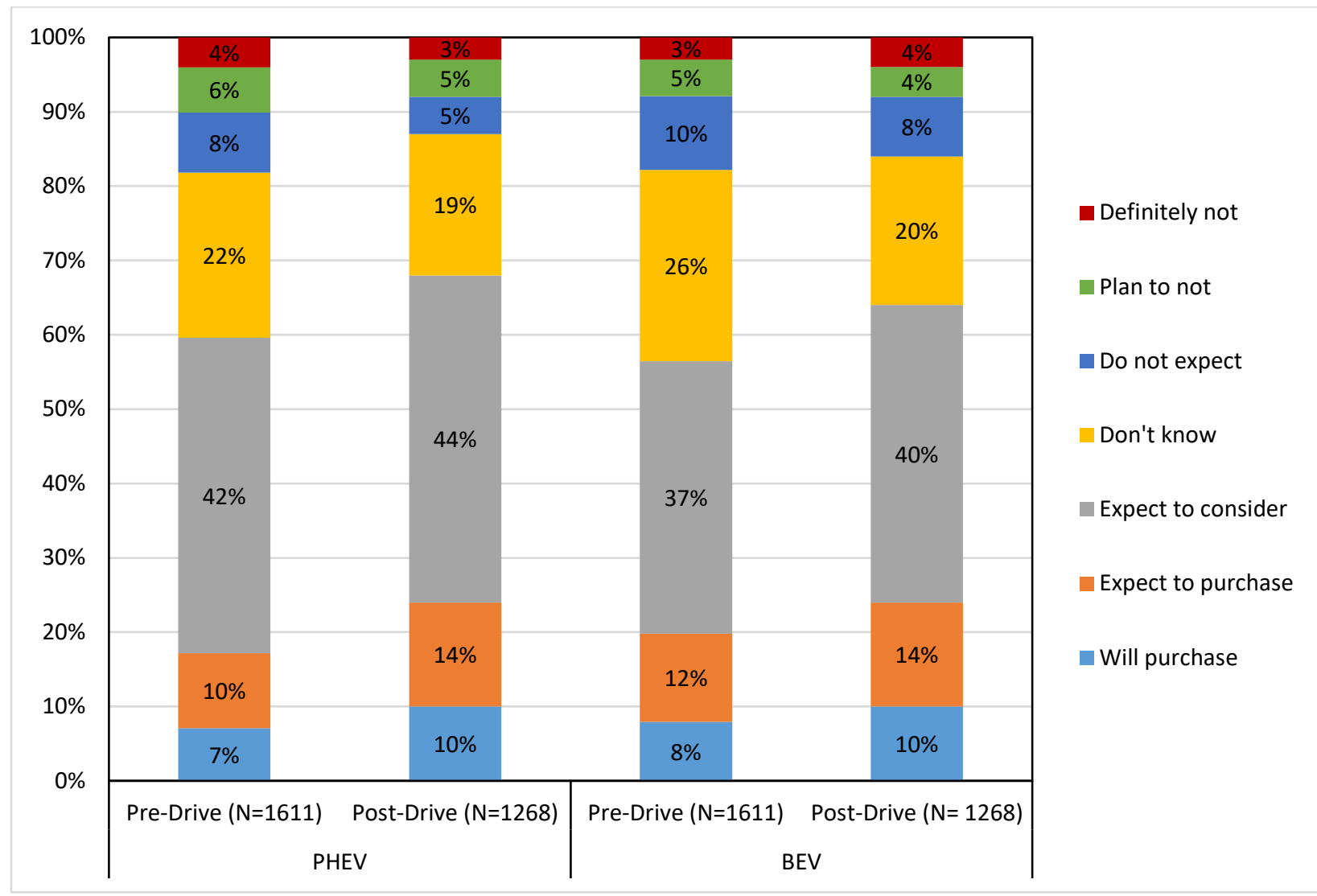

FIGURE 6 Pre- and post-drive opinions for PEVs in Midwest United States. ${ }^{[3]}$ 


\section{PROGRAMS TO ASSIST IN USED PEV ADOPTION}

\subsection{CHARGING INFRASTRUCTURE}

Over the past three decades, there has been a significant increase in the number of charging stations in the United States (Figure 7). Increasing the number of public charging outlets may be one way to increase the adoption of PEVs in general, but this may be even more important for used PEVs in low-income households that may not have access to residential charging.

California, which currently leads the United States in PEV adoption with about 350,000 electric vehicles registered as of 2017, accounts for about 5,500 ( 24\%) and 22,000 ( 32\%) of the charging stations and outlets in the United States, respectively. ${ }^{[36]}$ It would be interesting to know whether the significantly higher PEV adoption in California drives the higher number of charging stations, or vice versa, compared to other states. Note that other factors such as the Zero Emission Vehicle policy in California are also a likely factor for the high PEV adoption in that state. Electrify America, a wholly owned subsidiary of the Volkswagen Group of America, as part of a court-ordered settlement against the parent company, plans to have more than 3,000 chargers operational by the end of 2021 across the United States. Table 1 shows the number of public charging stations currently available in selected states in the United States.

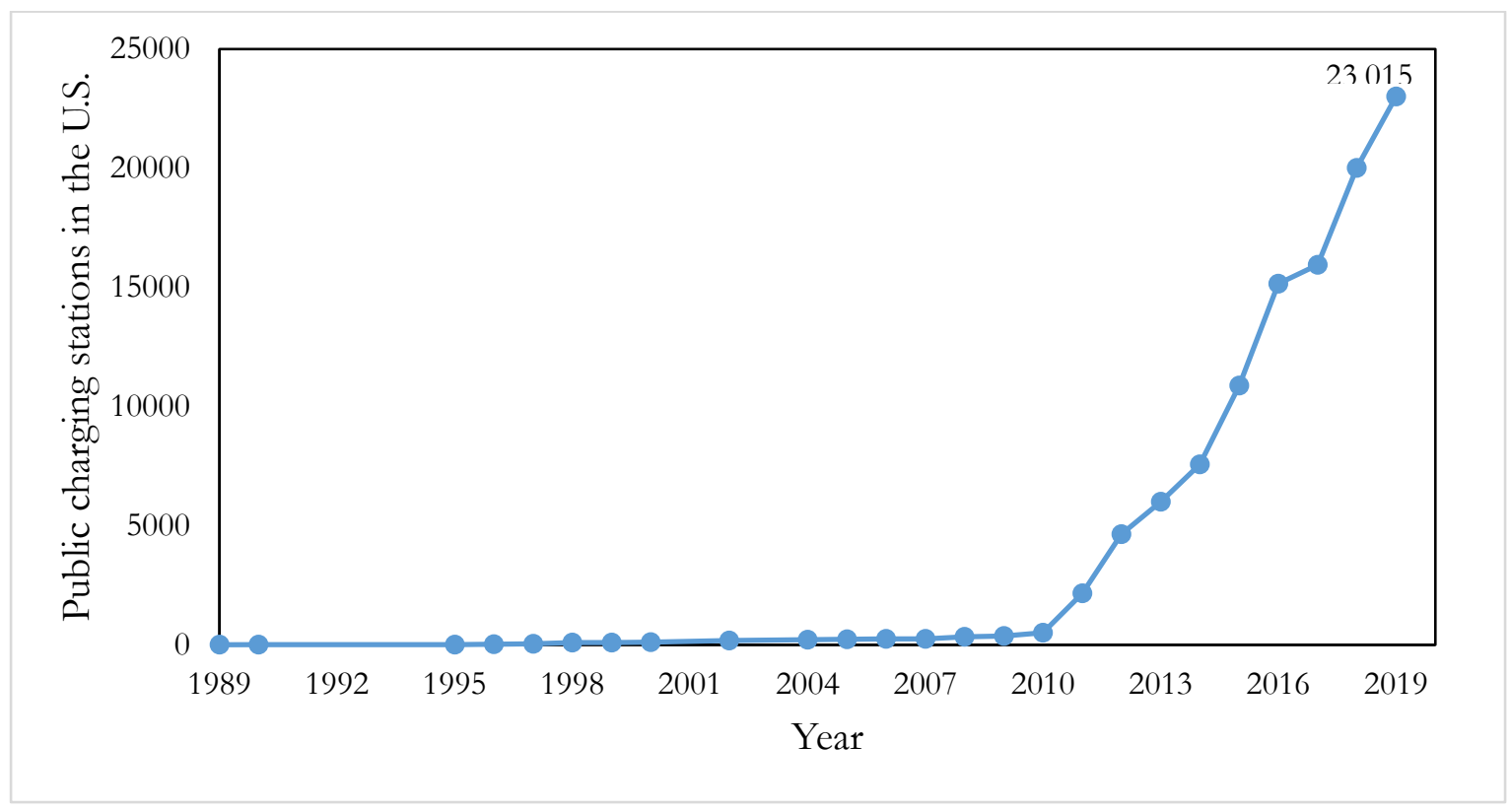

FIGURE 7 The number of public charging stations in the United States from 1989 to 2019. (Sources: years 1989-2017 $7^{[34]}$, year 2018 ${ }^{[35]}$, and year $2019^{[36]}$ ) 
TABLE 1 The number of public charging outlets in select states in the United States. (Source: Alternative Fuels Data Center ${ }^{[36]}$ )

\begin{tabular}{lc}
\hline \multicolumn{1}{c}{ State } & $\begin{array}{c}\text { Number of Public } \\
\text { Charging Outlets }\end{array}$ \\
\hline California & \\
New York & 21,604 \\
Florida & 3,552 \\
Texas & 3,321 \\
Washington & 3,284 \\
Colorado & 2,539 \\
\hline
\end{tabular}

\subsection{MONETARY INCENTIVES}

There are some incentives, both monetary and nonmonetary, in place to increase the adoption of PEVs. These incentives range from federal-level incentives to city-level incentives; even some utility companies offer incentives designed to increase PEV adoption. In 2010, a onetime federal tax credit was established in the United States to offer a tax credit of $\$ 7,500$ for the purchase of a new PEV. The tax credit is then halved once a PEV manufacturer has reached a threshold of 200,000-unit sales of its PEV models. Tesla, for instance, reached its 200,000-unit sales in 2018, resulting in current tax credits of $\$ 1,875$ for Tesla Models $3, \mathrm{~S}$, and X.

Some states and cities also offer incentives independent of the federal tax credit. As of February 2020, California offers sales incentives in the form of rebates (post-purchase) of either $\$ 2,000$ or $\$ 1,000$ for BEVs and PHEVs, respectively, through the Clean Vehicle Rebate Project (CVRP), while the Clean Vehicle Assistance Program (CVAP) provides grants (pre-purchase) of up to $\$ 5,000$ for new PEVs. ${ }^{[37,38]}$ As of March 2021, due to limited funding, CVAP is providing grants to applicants on a first-come, first-serve basis. As of 2019, Colorado provides tax credits up to $\$ 5,000$ for the purchase and $\$ 2,500$ for the lease of new PEVs. ${ }^{[39]}$ Oregon offers sales incentives up to $\$ 2,500$ depending on PEV battery capacity and income, while New York offers a rebate of $\$ 2,000$ depending on vehicle price. ${ }^{[40,41]}$

Some programs also provide additional incentives to low-income households. Through the CVRP, the sales incentive in California mentioned earlier offers a further rebate of about $\$ 2,000$ for low- and moderate-income households ( $\leq 300 \%$ of the federal poverty level) beyond the general rebate $(\$ 2,000)$ for all households, raising total incentives to about $\$ 4,000$ for lowincome households for the purchase of new BEVs. ${ }^{[37]}$ The CVRP in California also prioritizes rebate payments for low-income households. ${ }^{[37]}$ Oregon also offers a further rebate of $\$ 2,500$ for low- to moderate-income households beyond the general rebate $(\$ 2,500)$, raising the rebates for qualified low- to moderate-income households to $\$ 5,000$ for the purchase or lease of a new PEV.

Most of the programs mentioned earlier are, however, geared only toward the purchase of new PEVs, and only a few programs cater to the purchase of used PEVs. The $\$ 5,000$ grant 
offered by the California CVAP (which is not accepting applications as of January 2020) for income-qualified households also applies to the purchase of old PEVs. The CVRP in Oregon offers low- and medium-income household rebates of $\$ 2,500$ for the purchase or lease of used all-electric vehicles. ${ }^{[40]}$ Drive Forward Electric in partnership with Peninsula Family Service through the Peninsula Clean Energy (PCE) program offers vehicle incentives up to $\$ 4,000$ for income-qualifying San Mateo County, California, residents. This incentive from PCE is $\$ 2,000$ if "stacked" with other programs such as the CVAP. Utility company Southern California Edison offers up to a $\$ 1,000$ rebate for residential customers who purchase or lease eligible used and new PEVs. ${ }^{[42]}$ The Alternative Fuel Vehicle (AFV) rebate in Pennsylvania offers a $\$ 1,000$ rebate for eligible residents for the purchase of a one-time, pre-owned alternative fuel vehicle.

Figure 8 shows the direct incentives in the form of either grants (pre-purchase) or rebates (post-purchase) offered by state governments and utility companies in the United States. As mentioned earlier, some of these incentives can be stacked to further reduce the upfront purchase cost of used PEVs. However, there are some caveats on which incentives can be stacked and the amount of the incentives when stacked with other incentives. More details on the stacking requirements and eligibility for these incentives are provided on the websites of the different programs.

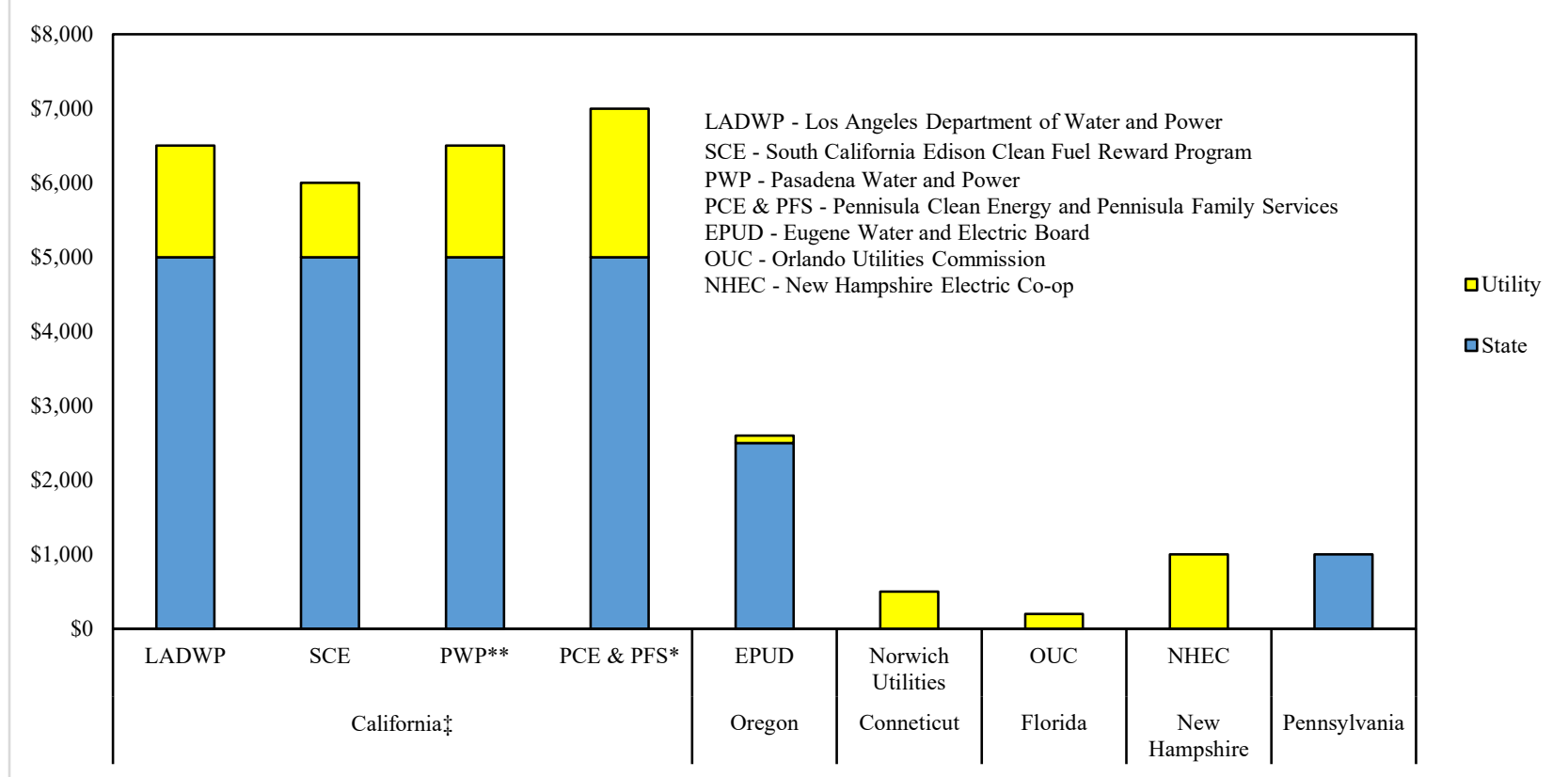

FIGURE 8 State and utility monetary incentives through grants or rebates for used PEVs in the United States.

* State incentive through the Clean Vehicle Rebate Project (CVRP); not accepting applications as of February 2020.

* Incentive from PCE \& PFS varies from \$2,000 to \$4,000 when stacked with the CVRP.

** Applies only to model year 2017 and newer.

(Consult programs for more details on incentives and eligibility requirements.) 
Research on the impact of financial incentives on the adoption of electric vehicles (mostly hybrid electric vehicles [HEVs]) is mixed. Some studies, such as that of Diamond, reported a weak relationship between incentive policies and HEV adoption, ${ }^{[43]}$ while Jenn et al. stated that incentives from the 2005 Energy Policy Act had a significant effect on HEV sales in the United States. ${ }^{[4]}$ In their study, Bjerkan et al. stated that of all the incentives for BEV adoption in Norway, the incentive that made the purchase price of the more-expensive BEVs almost equal to that of comparable ICEVs was the most critical aspect in promoting BEV sales. ${ }^{[45]}$ As shown in Figure 9, focusing on low-income households and using data from a California CVRP survey of those who applied for a rebate through the CVRP, Williams found that the percentage of low-income households (less than $\$ 49,999$ annually) that received the CVRP rebate for new PEVs increased from about 3\% around December 2015 to about $10 \%$ around June 2017.

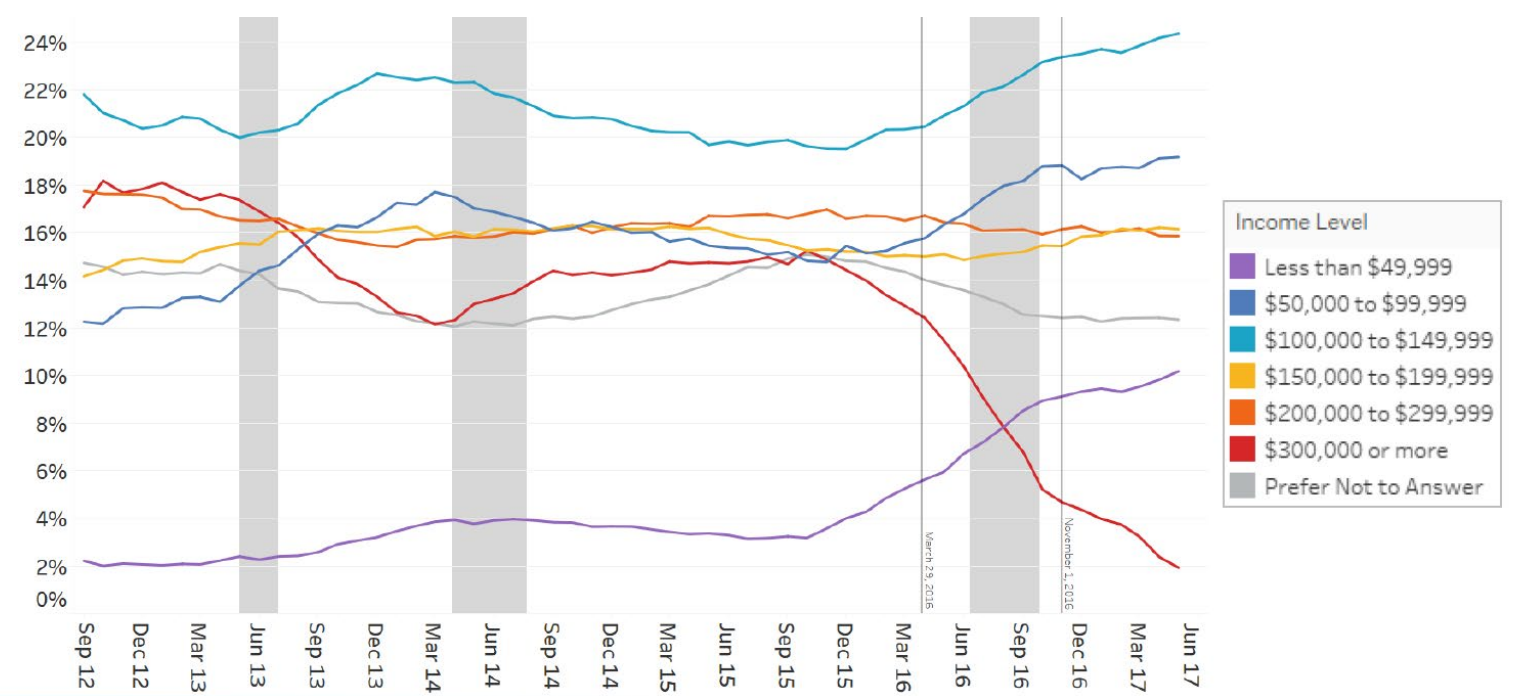

FIGURE 9 Impact of rebates on PEV purchases in California. ${ }^{[46]}$

While other factors, such as the CVRP prioritizing low-income applicants, may also contribute to the upward trend, Figure 9 shows that rebate incentives increased the participation of low-income households in the adoption of PEVs. A similar pattern may, therefore, be observed if there is an increase in the incentives for used PEV adoption in low-income households. Some programs, such as Clean Cars for All in California, also offer rebates or grants for used PEVs; however, these programs require income-qualified households to retire an older vehicle. Programs such as Clean Cars for All are not applicable within the context of lowincome, zero-vehicle households discussed in this paper and, therefore, are not included here.

Figure 10 shows monetary incentives in the form of rebates for the installation of residential charging infrastructure. Note that although this charging infrastructure incentive is applicable to all EV owners (new and used EVs), it is not limited to low-income households. Although the incentive does not apply directly to the purchase of an EV, it can improve household access to charging infrastructure as well as reduce range anxiety, and therefore possibly bolster EV adoption. As shown in Figure 10, this form of incentive is mostly provided by utility companies. 


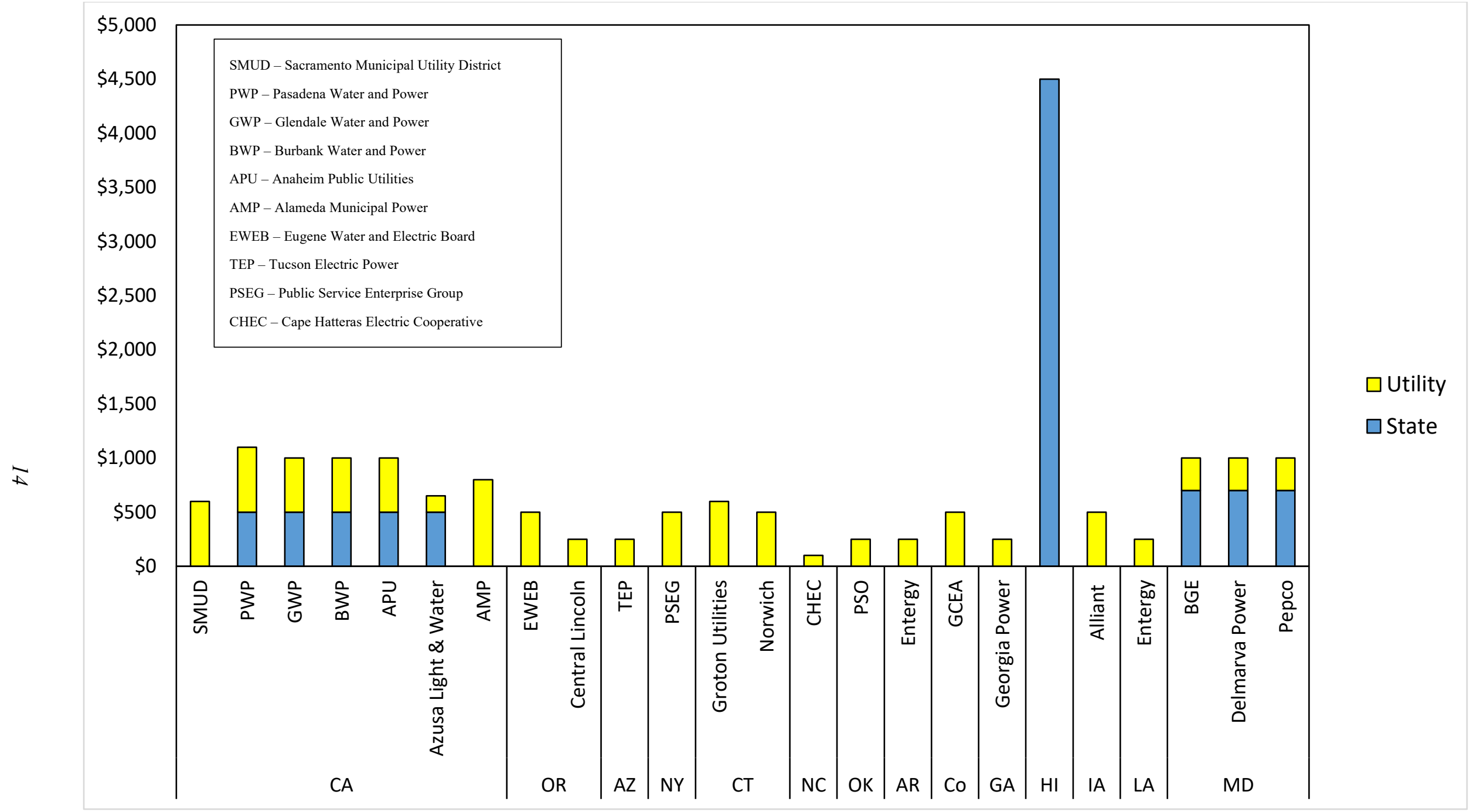

FIGURE 10 Incentives for PEVs in the form of rebates for electric-vehicle-charging infrastructure or electric vehicle registration. (Consult programs for more details on incentives and eligibility requirements.) 


\subsection{INCREASED PEV EXPOSURE}

One approach to addressing PEV misinformation is car- and ride-sharing programs focused on PEVs. Car- and ride-sharing typically provides access to vehicles for people who either do not have access to a vehicle or are looking to avoid expenses related to vehicle ownership. Including PEVs in such fleets will provide not only access but also personal experience by introducing future buyers to PEVs, which can help in assuaging some of the fears/misconceptions associated with PEV ownership. Survey results from Volvo Car USA/The Harris Poll (Figure 11) show that existing PEV drivers in the survey have significantly lower concerns about the main barriers to purchasing a PEV than the total driver population (of the 1,510 U.S. drivers 18 years and older in the poll).

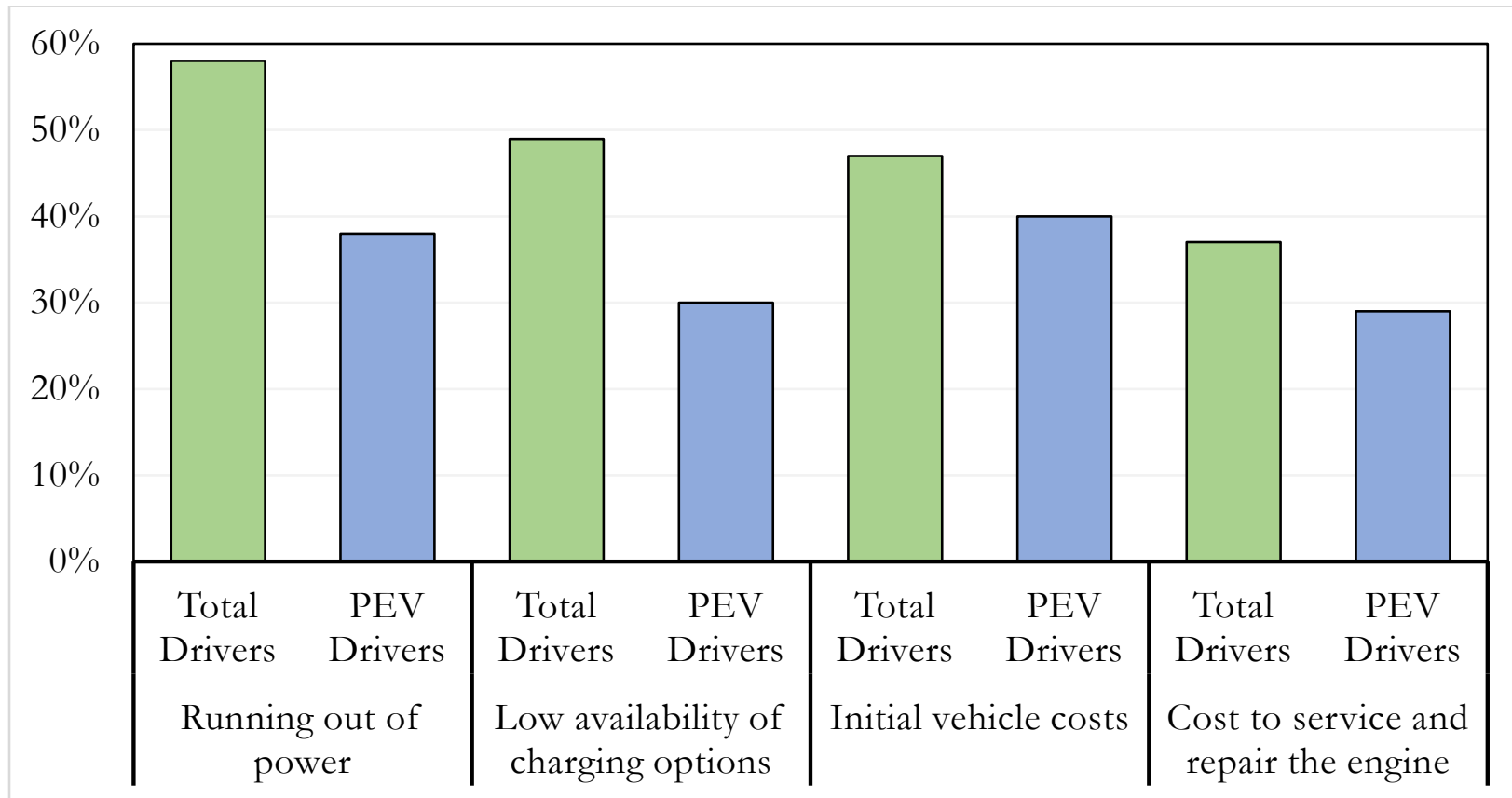

FIGURE 11 Comparison of the main barriers to PEV adoption between total driver population and existing PEV owners. (Adapted from EVAdoption ${ }^{[20]}$ )

One PEV car- and ride-sharing program aimed at low-income households is BlueLA, which currently offers lower rates ( 15 cents/minute) for low-income qualified households compared standard rates (20 cents/minute) and an annual membership fee of \$12 compared to the standard membership fee of $\$ 60 .{ }^{[47]}$ The Our Community CarShare program, a community pilot program operated by Zipcar in Sacramento, California, offers a free membership transportation service to communities in low-income areas through the city of Sacramento by providing PEVs for free for up to 3 hours per day or a total of 9 hours per week to eligible residents. The California Energy Commission awarded nearly \$3 million in 2017 to car-sharing programs that use electric vehicles in disadvantaged communities through Calstart, Inc. and Envoy Technologies to use BEVs for ride-hailing and car-sharing, respectively. ${ }^{[48]}$ Mutual Housing California, a company that owns and operates affordable housing in Sacramento, California, in 
partnership with the Sacramento Metropolitan Air Quality Management District, provides an electric car-sharing service for its resident members. ${ }^{[49]}$

\subsection{UTILITY COST REDUCTION}

Salisbury and Toor reported that electric utilities could benefit from PEV adoption if the PEV share of total vehicles becomes significantly large through the increase in electricity sales. ${ }^{[50]}$ Based on the U.S. Department of Energy 2015 Annual Energy Outlook that projected a continued decrease in the growth rates of electricity in the United States, Salisbury and Toor stated that "an increase in PEV adoption/penetration offers an opportunity to increase demand and potentially reverse the trend toward lower electricity sales." ${ }^{[47]}$ Also, increasing the adoption of PEVs by encouraging the participation of low-income households through low-cost and lowmaintenance used PEVs can benefit utility companies from an economies-of-scale standpoint in the deployment of a smart charging network, which will require some investment. The smart connected grid will help flatten the "duck curve" associated with electricity distribution in some regions, thereby evening out the load on the grid, limiting over-generation, and potentially lowering the electric utilities' cost for all consumers. In addition, electric utility companies are embracing the adoption of PEVs mainly through the deployment of charging infrastructure that, as noted earlier, will also ease some of the barriers to PEV adoption (range anxiety and limited access to charging stations) and balance the grid load. Pacific Gas and Electric, through its EV Charge Network program, in 2018 launched plans to deploy 7,500 charging stations at apartments, condos, and workplaces with $15 \%$ of the charging stations deployed in disadvantaged communities and $20 \%$ in multi-unit dwellings. ${ }^{[51,52]}$ 


\section{CONCLUSIONS}

Increasing the adoption of used PEVs by low-income households may be an opportunity to improve household-member mobility and, therefore, opportunity. The combination of low maintenance cost, low operating cost, and low purchase cost stems from the PEVs' fewer moving parts compared to ICEVs, low cost of electricity per mile compared to gasoline's price per mile, and used PEVs' lower cost compared to used ICEVs. These factors may make used PEVs more appealing for low-income households. Although access to low-cost and lowmaintenance PEVs will not alone move low-income households out of poverty, such access can improve their opportunities for higher-wage jobs and access to local services and amenities. Addressing the barriers highlighted earlier might, therefore, help increase the participation of low-income households in electric mobility. The low rate of technology adoption in low-income households, however, may be a barrier. Anderson and Kumar observed a disproportionate divide between low-income households and high-income households in the adoption of technological devices, such as smartphones and laptops. ${ }^{[53]} \mathrm{A}$ total of $71 \%$ of low-income households $(<\$ 30,000)$ polled had smartphones compared to $97 \%$ of high-income household $(\$ 100,000+)$, while only $54 \%$ of low-income households had a desktop or laptop computer compared to $94 \%$ of high-income households. ${ }^{[53]}$ This technology adoption barrier is no doubt partially driven by differences in disposable income, but it may illustrate the potential for an initial low adoption rate of PEVs in low-income households. Given the potential for used PEVs to be of material assistance to such households, it is important to address such barriers as they relate to PEV adoption. 


\section{REFERENCES}

1. Mitra, S. K., and J.-D. M. Saphores, "How do they get by without cars? An analysis of travel characteristics of carless households in California," Transportation, 2019: 1-22.

2. Silver, D., J. Blustein, and B. C. Weitzman, "Transportation to clinic: findings from a pilot clinic-based survey of low-income suburbanites," Journal of Immigrant and Minority Health, 2012, 14(2): 350-355.

3. Davis, S. C., and R. G. Boundy, Transportation Energy Data Book: Edition 38, 2018, Oak Ridge National Laboratory, Oak Ridge, TN.

4. Jones, P. B., et al., The Future of Transportation Electrification: Utility, Industry and Consumer Perspectives, Future Electric Utility Regulation Series, FUER Report No, 10, August 2018, Lawrence Berkeley National Laboratory, Livermore, CA.

5. Pendall, R., "For many low-income families, cars may be key to greater opportunity," 2014, Urban Institute. Available at https://www.urban.org/urban-wire/many-low-income-familiescars-may-be-key-greater-opportunity, accessed July 26, 2019.

6. Tomer, A., and R. Puentes, Transit access and zero-vehicle households, 2011, Metropolitan Policy Program, Brookings Institution, Washington, D.C.

7. Garasky, S., C. N. Fletcher, and H. H. Jensen, "Transiting to work: The role of private transportation for low-income households," Journal of Consumer Affairs, 2006, 40(1): 6489.

8. EnviroAtlas,"Number of Households with Zero Vehicles." 2015. U.S. Environmental Protection Agency. Available at https://enviroatlas.epa.gov/enviroatlas/DataFactSheets/pdf/Supplemental/NumberofHouseho ldsWithZeroVehicles.pdf, accessed July 16, 2019.

9. Brabo, L. M., et al., "Driving Out of Poverty in Private Automobiles," Journal of Poverty, 2003, 7(1-2): 183-196.

10. Padula, A. M., et al., "Traffic-related air pollution and risk of preterm birth in the San Joaquin Valley of California," Annals of Epidemiology, 2014, 24(12): 888-895. e4.

11. Clark, L. P., D. B. Millet, and J. D. Marshall, "National patterns in environmental injustice and inequality: Outdoor $\mathrm{NO}_{2}$ air pollution in the United States," PIOS ONE, 2014, 9(4): e94431.

12. Wang, Q., and D. L. Santini, Magnitude and value of electric vehicle emissions reductions for six driving cycles in four US cities with varying air quality problems, 1992, Argonne National Labratory, Argonne, IL.

13. Hawkins, T. R., et al., "Comparative environmental life cycle assessment of conventional and electric vehicles," Journal of Industrial Ecology, 2013, 17(1): 53-64.

14. Gohlke, David, and Zhou, Yan. Mon . "Assessment of Light-Duty Plug-in Electric Vehicles in the United States, 2010 - 2019”. United States. doi:10.2172/1642114. https://www.osti.gov/servlets/purl/1642114.

15. U.S. Energy Information Administration, "Electrified vehicles continue to see slow growth and less use than conventional vehicles," 2018, Today in Energy. Available at https://www.eia.gov/todayinenergy/detail.php?id=36312, accessed July 17, 2019.

16. Baik, Y., R. Hensley, P. Hertzke, and S. Knupfer, Making electric vehicles profitable, March 8, 2019, McKinsey \& Company. 
17. Sivak, M., and B. Schoettle, Relative Costs of Driving Electric and Gasoline Vehicles in the Individual US States, University of Michigan, Report No. SWT-2018-1, 2018. Available at http://umich. edu/ umtriswt/PDF/SWT-2018-1.pdf.

18. Energysage, How much do electric cars cost? 2019. Available at https://www.energysage.com/electric-vehicles/costs-and-benefits-evs/electric-car-cost/, accessed July 17, 2019.

19. Midwest EV Info List. Available at https://nebula.wsimg.com/1a8784efc87d2c4582c403ec3c8b01d1?AccessKeyId=25C1F3F6 D056BB3D70DD\&disposition=0\&alloworigin=1, accessed November 26, 2019.

20. EVAdoption, “" More Charging Stations' Biggest Factor to Increase EV Purchases: Volvo Car USA/The Harris Poll," March 11, 2019. Available at https://evadoption.com/morecharging-stations-biggest-factor-to-increase-ev-purchases-volvo-car-usa-the-harris-poll/, accessed July 17, 2019.

21. Hayes, J. G., et al., "Simplified electric vehicle power train models and range estimation," 2011 IEEE Vehicle Power and Propulsion Conference.

22. Nicholas, M., D. Hall, and N. Lutsey, Quantifying the electric vehicle charging infrastructure gap across U.S. Markets, white paper, January 2019, The International Council on Clean Transportation, Washington, D.C.

23. Bomey, N., "Thinking of buying an electric vehicle? Here's what you need to know about charging, " USA Today, January 25, 2018.

24. Davis, L.W., "Evidence of a homeowner-renter gap for electric vehicles," Applied Economics Letters, 2019, 26(11): 927-932.

25. Axsen, J., and K. S. Kurani, The early US market for PHEVs: Anticipating consumer awareness, recharge potential, design priorities and energy impacts UCD-ITS-RR-08-22, August 2008, Institute of Transportation Studies, University of California, Davis, CA.

26. Mayfield, D. and C. Collette, Siting electric vehicle charging stations, version 1.0, April 2012, Sustainable Transportation Strategies.

27. Batchelor, J., "EVs lose two thirds?" CarDealer, April 11, 2011.

28. Woodyard, C., "Depreciation hits electric cars hard," USA Today, December 26, 2013.

29. Guo, Z., and Y. Zhou, "Residual value analysis of plug-in vehicles in the United States," Energy Policy, 2019, 125: 445-455.

30. Schoettle, B., and M. Sivak, Resale Values of Electric and Conventional Vehicles: Recent Trends and Influence on the Decision to Purchase a New Vehicle, SWT-2018-4, March 2018, The University of Michigan, Sustainable Worldwide Transportation, Ann Arbor, MI.

31. Krause, R. M., et al., "Perception and reality: Public knowledge of plug-in electric vehicles in 21 U.S. cities," Energy Policy, 2013, 63: 433-440.

32. Knupfer, S. M., R. Hensley, P. Hertzke, and P. Shaufusss, Electrifying insights: How automakers can drive electrified vehicle sales and profitability, January 4, 2017, McKinsey \& Company.

33. Zhou, Y., Briones, D., and Rood, M., Midwest Evolve Data Summaries, 2019. (Personal Communication)

34. Mjcoren, "Public electric vehicles charging stations in the US," May 22, 2017, U.S.

Department of Energy, University of Michigan. Available at https://www.theatlas.com/charts/BJyIKBg7Z, accessed Sept. 11, 2019. 
35. Statista, "Number of public electric vehicle charging stations and charging outlets in the U.S. as of December 2018, ” Available at https://www.statista.com/statistics/416750/number-of-electric-vehicle-charging-stationsoutlets-united-states/, accessed Sept. 9, 2019.

36. Alternative Fuels Data Center, "Electric Vehicle Charging Outlets by State," n.d., U.S. Department of Energy, Energy Efficiency \& Renewable Energy. Available at https://afdc.energy.gov/data/10366, accessed Sept. 21, 2019.

37. Alternative Fuels Data Center, "Plug-In Hybrid and Zero Emission Light-Duty Vehicle Rebates," 2020. U.S. Department of Energy, Energy Efficiency \& Renewable Energy. Available at https://afdc.energy.gov/laws/8161, accessed Feb. 4, 2020.

38. Clean Vehicle Assistance Program, FAQ: Evolving Health and Economic Crisis Impacts on the CVA Program, "How much can I get towards a new or used hybrid or electric car?" 2020. Available at https://cleanvehiclegrants.org/faq/, accessed April 8, 2021.

39. Colorado Department of Revenue, Taxation Division, "Income 69: Innovative Motor Vehicle and Truck Credits for Electric and Plug-in Hybrid Electric Vehicles," 2019. Available at https://www.colorado.gov/pacific/sites/default/files/Income69.pdf, accessed August 27, 2019.

40. Alternative Fuels Data Center, "Plug-In Electric Vehicle (PEV) Rebate," 2019, U.S. Department of Energy. Available at https://afdc.energy.gov/laws/12139; accessed Sept. 25, 2019.

41. Alternative Fuels Data Center, "Plug-In Electric Vehicle (PV) Rebate Program," 2019, U.S. Department of Energy. Available at https://afdc.energy.gov/laws/11689, accessed Sept. 24, 2019.

42. Southern California Edison, "Go Electric, Get A Rebate," 2020. Available at https://evrebates.sce.com/, accessed Aug. 26, 2019.

43. Diamond, D. J., "The impact of government incentives for hybrid-electric vehicles: Evidence from US states," 2009, Energy Policy, 37(3): 972-983.

44. Jenn, A., I. L. Azevedo, and P. J. Ferreira, "The impact of federal incentives on the adoption of hybrid electric vehicles in the United States,” 2013, Energy Economics, 40: 936-942.

45. Bjerkan, K.Y., et al., "Incentives for promoting battery electric vehicle (BEV) adoption in Norway," 2016, Transportation Research Part D: Transport and Environment, 43: 169180.

46. Williams, B., "Opening Remarks and Implementation Perspective," 2019, Center for Sustainable Energy, San Diego, CA.

47. BlueLA, "Pay Less and Drive More, with the BlueLA Community Membership!" 2019. Available at https://www.bluela.com/pay-less-and-drive-more-bluela-communitymembership, accessed Oct. 25, 2019.

48. California Energy Commission, "Energy Commission Approves Electric VehicleRide Sharing Options in Disadvantaged Communities," 2017. Available at https://www.energy.ca.gov/news/2017-12/energy-commission-approves-electric-vehicleride-sharing-options-disadvantaged, accessed July 20, 2019

49. Mutual Housing California, "Car Share Program at Lemon Hill," 2019. Available at http://www.mutualhousing.com/community-organizing-at-mutual-housing/programs/, accessed August 19, 2019.

50. Salisbury, M., and W. J. Toor, "How and why leading utilities are embracing electric vehicles," July 2016, The Electricity Journal, 29(6): 22-27. 
51. Espino, J., "EV Update: PG\&E to Deploy EV Charging Stations in Low-Income Communities," January 19, 2018, The Greenlining Institute, Oakland, CA. Available at https://greenlining.org/blog-category/2018/pge-to-deploy-ev-charging-stations-in-lowincome-communities/, accessed July 16, 2019.

52. Pacific Gas and Electric Company (PG\&E), "The EV Charge Network program," 2019. Available at https://www.pge.com/en_US/large-business/solar-and-vehicles/cleanvehicles/ev-charge-network.page, accessed Aug. 19, 2019.

53. Anderson, M., and M. Kumar, "Digital divide persists even as lower-income Americans make gains in tech adoption," May 7, 2019, Pew Research Center. 
This page left intentionally blank. 



\section{Argonne}

\section{Energy Systems Division}

Argonne National Laboratory

9700 South Cass Avenue, Bldg. 362

Argonne, IL 60439

www.anl.gov 